\title{
PREDICTION SCORE FOR COMPLICATIONS AFTER COLORECTAL CANCER SURGERY BASED ON NEUTROPHILS/LYMPHOCYTES RATIO, PERCENTAGE OF IMMATURE GRANULOCYTES, IG AND IT RATIOS
}

\author{
LJILJANA MAYER ${ }^{1}$, SANJA LANGER ${ }^{1}$, MIHAELA GAĆE ${ }^{1}$, PERO HRABAČ ${ }^{4}$, \\ MILICA ŠOSTARIĆ ${ }^{1}$, INES FIJAN ${ }^{1}$, ZVJEZDANA ŠPACIR PRSKALO ${ }^{1}$, ANA CVETKO ${ }^{5}$, \\ JOSIPA PERIŠA ${ }^{6}$, LJILJA ŠTEFANČIĆ ${ }^{3}$, IVAN PENAVIĆ ${ }^{2}$, HRVOJE TOMASOVIĆ ${ }^{2}$, \\ GORDANA BROZOVIĆ ${ }^{3}$, DANKO VELIMIR VRDOLJAK ${ }^{2}$
}

${ }^{1}$ Department of Medical Biochemistry in Oncology, University Hospital for Tumors, Sestre milosrdnice University Hospital Center, Zagreb, Croatia;

${ }^{2}$ Department of Surgical Oncology, University Hospital for Tumors, Sestre milosrdnice University Hospital Center, Zagreb, Croatia;

${ }^{3}$ Departmanet of Anaesthesiology, Reanimatology and Intensive Care Medicine, University Hospital for Tumors, Sestre milosrdnice University Hospital Center, Zagreb, Croatia; ${ }^{4}$ Croatian Institute for Brain Research, School of Medicine, University of Zagreb, Zagreb, Croatia;

${ }^{5}$ Department of Biochemistry and Molecular Biology, Faculty of Pharmacy and Biochemistry, University of Zagreb, Zagreb, Croatia;

${ }^{6}$ Department of Oncology and Nuclear Medicine, Sestre milosrdnice University Hospital Center, Zagreb, Croatia

\footnotetext{
Summary

Introduction: The markers of inflammations are a significant predictor of postoperative outcome after colorectal cancer surgery. Along with leukocytes, C-reactive protein (CRP), procalcitonin (PCT) and neutrophil/lymphocyte ratio (NLR) we tried to test the role of immature granulocytes (IG) counts and trends in the postoperative period.

Methods: We recorded matched three patient according to their sex, age, and tumor localization who had an uneventful recovery with three patients who had an anastomotic leak required reoperation. We obtained the IG count with every complete blood count and correlated these with CRP, PCT, NLR. For the best prediction we calculated the potential Zagreb score by adding 1 point for elevated NLR ratio for more than 75\%, minimally three consecutively elevated \% IG, doubling of immature granulocytes relative value to absolute neutrophils count ratio (IG ratio) and immature granulocytes relative value to leucocytes count ratio (IT ratio) at three consecutive time points.
}

Results and Conclusion: Potential Zagreb score seems to predict the need for reoperation in time. Herein we introduce its concept, and we plan the retrospective study to test its feasibility and precision.

KEYWORDS: Zagreb score, immature granulocytes, C-reactive protein; neutrophil/leucocyte ratio, colorectal cancer 


\section{POTENCIJALNI PREDIKTIVNI BILJEZI POSTOPERATIVNIH KOMPLIKACIJA KOLOREKTALNOG KARCINOMA TEMELJENI NA OMJERU NEZRELIH GRANULOCITI I LIMFOCITA, UDJELU NEZRELIH GRANULOCITA TE IG I IT OMJERU}

\section{Sažetak}

Uvod: Markeri upale su važni čimbenici u predviđanju poslijeoperacijskog tijeka u kolorektalnoj kirurgiji. Uz leukocite, $\mathrm{C}$ reaktivni protein, prokalcitonin i neutrofilno/limfocitni omjer, uvodimo mogućnost korištenja broja i trendova nezrelih granulocita u postoperacijskom periodu.

Metode: Zabilježili smo kliničke podatke tri pacijenta koja su imala uredan poslijeopracijski tijek i tri koja su imala dehiscencu anastomoze. Pacijenti su upareni po dobi, spolu, i lokalizaciji karcinoma kolorektuma. Obradili smo podatke o broju nezrelih granulocita koji je integralni dio kompletne krvne slike na analizatoru Sysmex XN 1000, te korelirali podatke sa CRP-om, PCT-om, NLR-om. Najbolje predviđanje smo dobili kada je ustanovljen potencijalni Zagreb score: povećan NLR za više od 75\%, tri povećanja \% IG zaredom i udvostručenje IG-a and IT-a u tri mjerenja zaredom.

Rezultati i zaključak: Potencijalni Zagreb score je predvidio potrebu za reoperacijom na vrijeme. Ova serija slučajeva je uvela koncept i planiramo retrospektivno, na većem uzorku, testirati izvedivost i preciznost potencijalnog Zagreb scorea.

KLJUČNE RIJEČI: Nezreli granulociti, C reaktioni protein, omjer neutrofila i leukocita, kolorektalni karcinom

\section{INTRODUCTION}

The inflammatory response is present in all tumor stages (initiation, promotion, malignant conversion, invasion, metastatic disease). Inflammation can be induced by the tumor itself, through secretion of the factors of granulocytopoesis or inflammatory mediators such as tumor necrosis factor, interleukin 1 and 6 . All these markers are measurable in absolute number in circulation $(1,2)$. Both absolute numbers and their ratios are rather sensitive in predicting the overall outcome with pretreatment values, as well as in signaling of complications during treatment. Most common predictors are C-reactive protein (CRP), procalcitonin (PCT), and leucocyte count (L). However, the ratios of these markers might be more sensitive in some cases. In inflammation, a neutrophilia is followed by lymphopenia, which reduces the capacity of cytotoxic lymphocytes, thus compromising the mechanism of reducing the number of tumor cells(3). Therefore, the ratio of the absolute number of neutrophils and lymphocytes (NLR) is considered an excellent early indicator of complications and worse overall outcome predictor.

Until recently, only insight in immature granulocytes quantification was manual differentiation. Development of hematology analyzer technology in the last decade resulted in sophisticated analytical systems of exceptional complexity which unified numerous different detection measuring principles for blood cells quantification, identification, and characterization in whole blood samples as well in body fluid samples. Im- pedance and hydrodynamic focusing are used for estimating the number and size of red blood cells and platelets; flow cytometry for analyzing physical and chemical characteristics of leukocytes (size, granularity). The cells, in laminar flow, pass through the beam of the laser and are classified by the measurement of the intensity of emitted fluorescence and light scattered by each cell. At the same time, analyzer measures cell parameters by cellular DNA quantification. For purposes of analyzing pediatric hematology patients blood results, we introduced new methods for quantifying the whole blood.

As a result, we observed that a parameter appearing in the output - IG count/percentage - seem to correlate well with markers of inflammation and NLR. Immature granulocytes (promyelocytes, metamyelocytes, myelocytes, and band cells) in the systemic circulation indicate intensive bone marrow activation. The IG absolute number normal value for both genders was $0,03 \times 10^{9} / \mathrm{L}$; while the IG relative percentage was below $0.5 \%$ in men and $0.4 \%$ in women genders (4).

All markers of inflammation: leukocytes, CRP, PCT, the absolute number and proportion of IG, independently, or expressed as ratios (IT ratio and IG ratio) might be a tool in early diagnosis of complications in the postoperative period. In such cases, there is a comparative advantage of NLR, \% IG, IG, and IT is easy availability and short time for getting laboratory results (short turn around time). Those parameters are part of the complete blood count and do not require the delay time because of pre-analytical issues like PCT and CRP 
(unavoidably spontaneous coagulation and centrifugation, and finally the time of analysis at biochemical or immunochemical analyzer defined by the application).

Based on these data, we decided to look into the role of IG, IG, and IT ratios and NLR and their combinations in predicting the complications after colorectal surgery matched pairs series.

\section{MATERIALS AND METHODS}

From 1st November 2015 until 1st June 2016, we recorded laboratory findings and postoperative patient's clinical status in patients who were operated for localized colorectal cancer. Patients were matched by age, sex, and tumor localization. Trends were recorded for total white blood cell count (WBC), absolute and relative proportion of neutrophils and lymphocytes, NLR, IG and IT ratios, PCT and CRP in three patients who had an uneventful first perioperative week and three of patients who developed complications which required reoperation. Based on recorded laboratory trends for both series of patients, we derived the score.

\section{RESULTS}

\section{Case 1a}

Patients history: Eighty-one-year-old woman had sigmoid colon resected for colorectal mucinous adenocarcinoma (pT2N0cM0). Significant comorbidity is insulin-dependent diabetes. Her recovery in ICU was slow and on a postoperative day (POD) 5 after being discharged to the surgical ward, later in the evening she vomited, complained of intra-abdominal pain and was distended. After CT scan, showed free liquid and her state deteriorate she was reoperated on POD (6), intraoperatively anastomotic leak found and after disconnection, colostomy was formed. Patient's state further deteriorated during her state in ICU, and on POD 7, the patient died.

Laboratory findings: On POD3, a significant elevation in NLR was recorded (the value doubled). Simultaneously, lymphocyte count elevated for $30 \%$. There was an elevation in values of $\%$ IG in three consecutive time points. On POD3 CRP and PCT were slightly elevated, while IG ratio and
IT ratio followed elevated \% IG, in all three-time point.

\section{Case 2a}

Patients history: Fifty-three-year-old male patient was operated for sigmoid colon adenocarcinoma (pT3N1acM0). POD5, the patient was discharged to the surgical ward. On POD7 patient complained of the acute onset of abdominal pain. There was a stool discharge through the drain wound. The patient was reoperated for partial anastomotic defect, and protective ileostomy was formed. The postoperative recovery after the second operation was uneventful.

Laboratory findings: On POD6, we recorded doubled values of NLR. Simultaneously the leucocyte count remains the same, but CRP and PCT also doubled. On POD5, we recorded the elevation of IG in three consecutive time points. IG and IT ratio became elevated on POD4.

\section{Case 3a}

Patients history: Forty-six-year-old male patient was operated for rectal adenocarcinoma (yT3N1cM0). On POD4, he became distended with acute onset of abdominal pain. Reoperation was indicated. The intraoperatively partial anastomotic defect was found, additional sutures were placed, and protective ileostomy was formed. Subsequent postoperative recovery was uneventful.

Laboratory findings: Throughout the postoperative period, the neutrophil count was elevated. On POD2 N/L count doubled. Simultaneously, the leucocyte count was elevated for $25 \%$.

\section{Case $1 b$}

Patients history: Sixty-year-old female patient was operated for sigmoid adenocarcinoma (Tis, N0, M0). Postoperative recovery was uneventful.

\section{Case $2 b$}

Patients history: Sixty-nine-year-old female patient was operated for rectal adenocarcinoma (pT2N1aCM0). Postoperative recovery was uneventful.

\section{Case $3 b$}

Patients history: Seventy-seven-year-old female patient was operated for sigmoid villous ad- 
Table 1.

ZAGREB SCORE: IS CALCULATED BY ADDING 1 POINT FOR ELEVATED NLR FOR MORE THAN $75 \%$, MINIMALLY THREE CONSECUTIVELY ELEVATED \%IG, DOUBLING OF IG AND IT RATIO AT THREE CONSECUTIVE TIME POINTS. THE TABLE SHOWS THE POTENTIAL ZAGREB SCORE APPLICATION IN THIS PILOT CASE SERIES.

\begin{tabular}{|c|c|c|c|c|c|}
\hline & 1 & 2 & 3 & $\begin{array}{l}\text { Zagreb score } \\
\quad(1+2+3)\end{array}$ & \multirow{2}{*}{$\begin{array}{c}\text { Concordance } \\
\text { with the outcome }\end{array}$} \\
\hline & $\begin{array}{l}\text { Elevated NLR for } \\
\text { more than } 75 \%=1\end{array}$ & $\begin{array}{c}\text { Minimally three consecutively } \\
\text { elevated } \% I G=1\end{array}$ & $\begin{array}{l}\text { Doubling of IG and IT ratio at three } \\
\text { consequtive time points = } 1\end{array}$ & $\begin{array}{l}\text { Sum of three } \\
\text { factors }\end{array}$ & \\
\hline Case 1a & 1 & 1 & 1 & 3 & Yes \\
\hline Case $2 a$ & 1 & 1 & 1 & 3 & Yes \\
\hline Case $3 a$ & 1 & 1 & 1 & 3 & Yes \\
\hline Case $1 \mathrm{~b}$ & 0 & 0 & 0 & 0 & Yes \\
\hline Case $2 b$ & 0 & 0 & 0 & 0 & Yes \\
\hline Case $3 b$ & 0 & 0 & 0 & 0 & Yes \\
\hline
\end{tabular}

enoma with high-grade dysplasia. The patient was a diabetic with a previous operation of malignant melanoma of the right sole. Postoperative period was uneventful.

Laboratory findings: On consecutive postoperative days absolute number of leucocyte, the absolute number of neutrophils, NLR fall. There is a slight elevation of CRP, followed by leucocytes and neutrophils discrete elevation on POD3. There was no elevation of PCT nor consecutive elevations of \% IG, nor the doubling of IG ratio or IT ratio.

\section{DISCUSSION}

We recorded colorectal cancer patients' data and their inflammatory response in the postoperative period. Each operation by itself triggers an acute inflammatory response. It is known that laparoscopic operation has lower perioperative inflammation markers (5), however, in our center, most patients have an advanced disease where we opt for open surgery, which means that part of the inflammatory response might be due to laparotomy itself.

Nevertheless, colorectal cancer surgery is burdened with a considerable complication rate (6). One of the major complications is an anastomotic leak which often requires reoperation. The decision for reoperation is based on clinical findings such as acute abdominal pain, vomitus, and diarrhea, tachycardia, fever in combination with laboratory tests for inflammation: complete blood count (CBC), PCT, CRP, NLR. Tests that can evaluate patients immune response quickly and reli- ably are beneficial in making the decision. In the end, the surgical decision can vary from a watch and wait to the most urgent relaparotomy depending on the extent of inflammation and leak.

Currently, the most researched and widely used laboratory parameter is the NLR. The connection between preoperative NLR with the overall survival in colorectal cancer was observed a decade ago $(7,8)$. In most publications, CRP, NLR, and PCT are considered separately. Trends of standard inflammation markers in the perioperative period after open surgery have been recorded on our larger series of non-eventful patients (Figure 1) and are in line with published data.

The change in our equipment provided the count of IG incorporated within the complete blood count. In terms of time within five minutes of sample arrival in the laboratory, while CRP and PCT require at least an hour for technical reasons, and these two can sometimes be in disparity. The postoperative trends of IG seem to follow the trends of CRP and PCT, perhaps even with a slight time edge. We retrospectively analyzed the perioperative trend in reoperated patients and compared those with uneventful postoperative recovery patients. From the observed trends in this sample, we derived three elementary conditions which predicted reoperation at least 24 hours before the clinical decision. We defined the criteria for potential Zagreb score: elevated NLR for more than $75 \%$ (1 point), doubling of IG and IT ratio at three consecutive times ( 1 point) and minimally three consecutively elevated \% IG. The sum of three predicted the reoperation in all cases while none of the criteria was in concordance with un- 
complicated recovery. The trend seems promising, and the validation will be performed on a large cohort.

Good correlation between relative IG percentage and standard inflammatory response indicators was confirmed by research in which at patients with IG equal or greater than $2.0 \%$; CRP was elevated in $84 \%$ of them, ESR and CD64 in $95 \%$ and $80.3 \%$ them (9). Besides the proof that IG\% was higher in patients with positive haemoculture, it seems that it is a better predictor of infection than the total number of leukocytes, and it is comparable to the absolute number of neutrophils. Also, the value IG>3\% considered as a reliable predictor of sepsis (at $90 \%$ of patients)(10). Some authors suggested others calculation models, or a way for expressing the number of immature granulocytes in the proportions: IG ratio $=\%$ IG / total number of leukocytes, and IT ratio $=\%$ IG / total number of neutrophils. On that way, the cut-off values, which reached maximum sensitivity and specificity for IG ratio is 0.35 ; and for IT is 0.65 . The positive predictive value for IT higher than 0.65 was $74 \%$ at $74 \%$ sensitivity and $50 \%$ specificity. The standard value for IT is less than 0,2 . Positive predictive value of IG higher than 0.35 was $68 \%$ at $74 \%$ sensitivity and $35 \%$ specificity (11). Justification of such mathematical transformation models was confirmed and improved the positive and negative predictive value of IT concerning the IG (74\% vs. $50 \%$ and 68 vs. $41 \%)$ and the fact that IT in patients with negative blood cultures proved to be a useful additional parameter (100 PPV). Research Nierhaus et al. showed that the number of immature granulocytes could serve as a useful diagnostic marker in discrimination SIRS and sepsis in ICU patients (12).

The limitation of our observation is the small sample size (analysis on a large cohort is underway) and difficulty to derive a timeline for clinical symptoms onset from the records. On the other hand, knowing this to be an issue, an objective test might be a crucial point in deciding to reoperate the patient.

\section{REFERENCES}

1. Lord BI, Bronchud MH, Owens S, Chang J, Howell A, Souza L, Dexter TM. The kinetics of human granulopoiesis following treatment with granulocyte colony- stimulating factor in vivo. Proc Natl Acad Sci USA. 1989;86(23):9499-503.

2. Hofman PM. Pathobiology of the neutrophil-intestinal epithelial cell interaction: role in carcinogenesis. World J Gastroenterol. 2010;16(46):5790-800.

3. Gooden MJ, de Bock GH, Leffers N, Daemen T, Nijman HW. The prognostic influence of tumour-infiltrating lymphocytes in cancer: a systematic review with meta-analysis. Br J Cancer. 2011;105(1):93-103.

4. Brugel M, Fiedler GM, Matthes G, Thyery J. Reference values for immature granulocytes in healthy blood donors generated on the Sysmex. XE-2100 Automated Hematology Analyser. Sysmex J Int. 2004;14:5-7.

5. Zelić M. Laparoscopy in treatment of malignanat colorectal diseases. Libri Oncologici. 2013; 41(1-3):21-26.

6. Sheikh L, Croft R, Harmston C. Counting the costs of complications in colorectal surgery. N Z Med J. 2019 Jun 21;132(1497):32-36.

7. Walsh SR, Cook EJ, Goulder F, Justin TA, Keeling NJ. Neutrophil-lymphocyte ratio as a prognostic factor in colorectal cancer. J Surg Oncol. 2005;91(3):181-4.

8. Solak Mekić M, Pedišić I, Šobat H, Vučićević Boras V, Kirac I, Štefančić L, Šekerija M, Vrdoljak B, Vrdoljak DV. The role of complete blood count parameters in patients with colorectal cancer. Acta Clin Croat. 2018;57(4):624-629.

9. Briggs C, Kunka S, Fujimoto H, Hamaguchi Y, Davis $\mathrm{BH}$, Machin SJ. Evaluation of immature granulocyte counts by the XE-IG master: upgraded software for the XE-2100 automated hematology analyzer. Lab Hematol. 2003;9(3):117-24.

10. Ansari-Lari MA, Kickler TS, Borowitz MJ. Immature granulocyte measurement using the Sysmex XE-2100. Relationship to infection and sepsis. Am J Clin Pathol. 2003;120(5):795-9.

11. Iddles C, Taylor J, Cole R, Hill FGH. Evaluation of immature granulocyte count in the diagnosis of sepsis using the Sysmex XE-2100 analyser. Sysmex J Int. 2007;17:20-29.

12. Nierhaus A, Klatte $S$, Linssen J, Eismann NM, Wichmann D, Hedke J, Braune SA, Kluge S. Revisiting the white blood cell count: immature granulocytes count as a diagnostic marker to discriminate between SIRS and sepsis--a prospective, observational study. BMC Immunol. 2013;14:8.

Corresponding author: Ljiljana Mayer, Department of Biochemistry, University Hospital for Tumors, Sestre milosrdnice University Hospital Center, Ilica 197, 10000 Zagreb, Croatia.e-mail: ljiljana.mayer@kbcsm.hr 